\title{
Biochemical and Hematological Analysis after Exposure to Hazardous Materials during Shoe Making
}

\author{
Ayaz Ali Khan (Corresponding author) \\ Assistant Professor, Department of Biotechnology, University of Malakand \\ Chakdara, Dir (Lower), Khyber Pakhtunkhwa, Pakistan \\ Tel: 92-345-886-0677Ｅmail: lalatejan@gmail.com
}

Reshma Sultan

M. Sc. Student, Department of Zoology, University of Malakand

Chakdara, Dir (Lower), Khyber Pakhtunkhwa, Pakistan

Tel: 92-344-966-1561Ｅmail: Mohdsaim94@gmail.com

Ghazala Yasmeen Zamani

Lecturer, Department of Biotechnology, Bacha Khan Unviersity

Charsada, Khyber Pakhtunkhwa,Pakistan

Tel: 92-333-950-8759Ｅ-mail: ghazala.zamani@yahoo.com

\section{Saleem-Ur-Rahman}

M. Phil Scholar, Department of Biotechnology, University of Malakand

Chakdara, Dir (Lower), Khyber Pakhtunkhwa, Pakistan

Tel: 92-344-924-1218Ｅ-mail: saleemurrrahman20@gmail.com

Received: February 15, 2013 Accepted: March 6, 2013

doi:10.5296/jbls.v4i2.3260 URL: http://dx.doi.org/10.5296/jbls.v4i2.3260

\section{Abstract}

The use of organic solvents indoors as well as outdoors causes severe toxic effects on both the 
occupants and non-occupants. In the present study, effects of shoe polish, organic solvents, and adhesives on the health status of shoe makers in upper district Swat, Khyber Pakhtunkhwa, Pakistan were evaluated. Histories and blood samples were taken from both the exposed and non-exposed people. Blood biochemical parameters and hematological analysis was performed using UV Double Beam Spectrophotometer and Fully Automated Hematology Analyzer SYSMIX (Japan). There was significant increase in blood triglyceride, cholesterol, low density lipoprotein, high density lipoprotein, serum glutamate pyruvate transaminase, alkaline phosphatase, creatinine, and uric acid level of workers. No effect on blood glucose level was observed in workers as compared to non-exposed control. In shoe making workers, the results for hemoglobin level, total red blood cells count, hematocrit value, mean corpuscular volume, mean cell hemoglobin level, mean cell hemoglobin concentration were normal. There was significant increase in total leukocyte count, lymphocytosis, Eosinophilia and monocyte count in shoe making workers as compared to control. A significant decrease was observed in platelets and neutrophil count of workers when compared to the control group. The results showed an alteration in biochemical parameters and up to some extent in hematological parameters in exposed workers as compared to control. The study suggests that these people are at a higher risk to various health hazards as compared to those who are not exposed to such environment. Concentration of these compounds must be measured so that proper protective measures may be adopted by the workers. Also same study involving a large population size is also recommended to identify other health problems related to exposure to these chemicals.

Keywords: Biochemical parameters, Complete Blood Profile, Shoe making workers, Organic solvents

\section{Introduction}

Shoe polish manufacture is one of the oldest occupations. Various risk factors which include noise, dust and hazardous substances due to exposure to different organic and inorganic chemical (Elci et al 2007) contribute to health problems in cobblers. Leather dust, petroleum products, metals and solvents are the main risk factors to shoe makers (Isci Sagligi Dernegi 1992). As per other research studies, chemical exposure, noise and stress lead to cancer, musculoskeletal injuries and neuropsychiatric disorders (Jockel et al 2000, Fu et al 1996 and Armstrong 1995). People working in this kind of environment near busy roadways are at risk to elevated levels of air pollutants from external sources like vehicle exhausts and also from shoe dust, organic solvents, adhesives and shoe polish during working hours (Bae et al 2004). Many toxic chemicals, together with organic solvents to which humans are occupationally or non-occupationally exposed, having its physicochemical characteristics with different absorption routes and target organs. These have been confirmed to have toxicity in many organs (Xiao and Levin 2000) including the liver (Warnes et al 1999), hematopoietic organs (Natelson 2007), nervous system (White and Proctor 1997), immune endocrinological system (Wichmann et al 2005), kidney, cardiovascular system, skin, mucosa, and reproductive organs, and body homeostasis maintenance function (Merker et al 2006). The short term problems which can occur in shoe workers are irritation of the eyes, nose and throat, headache, dizziness, and confusion (Ukai et al 1993, Ukai et al 1994). The long term effects are neurological and psychological disorders (Elci et al 2007). The neurological disorders in shoe makers are due to 
destruction of neurotransmitters, enzymes, essential and trace elements inside the body (Alkan et al 2004). The earlier reports show that people who work on such sites where benzene concentration is high have physical discomfort, energy metabolism dysfunction and also changes in their blood glucose level (Dere et al 2003). Liver, kidney, lungs, heart and brain are also target sites of benzene which can also cause chromosomal damage and break DNA strands (Rana and Verma 2005). Toluene leads to nervous system disorders, renal and hepatic damage (Hadded and Winchester 1990, James and Martindale 1996). Xylene, toluene and n-hexane have neurotoxic, myotoxic and hepatotoxic effects (Akisu et al 1996). Exposure to chemicals might also lead to liver injury (Soyinka et al 2007). Analysis of liver enzymes shows hepatotoxicity. Alanine amino transferase (ALT) and asparitine amino transferase (AST) are most frequently measured enzymes which reflect hepatotoxicity (Douidar et al 1992). The kidney is also susceptible to a wide range of nephrotoxins which differ in their nephrotoxic effects from mild renal dysfunction to severe damage and end stage renal failure (Price 2000). Several studies have been carried out on those workers exposed to solvents but only a few studies have analyzed that toluene exposure leads to renal dysfunction (Stengel et al 1998). In the present study we studied the effect of chemicals used in mini shoe making industries on different blood components and hematological parameters of shoe making workers.

\section{Materials and Methods}

\subsection{Sampling Area}

History was taken and blood samples were collected from different shoe making workers and also from people living all around the area at Behrain, Madyan and Fatehpur at district Swat, Khyber Pakhtunkhwa, Pakistan during December 2011 till March 2012. The study was approved by the ethical board of University of Malakand, Chakdara, Dir (Lower), Khyber Pakhtunkhwa, Pakistan.

\subsection{Collection of Blood Samples from Workers and Control}

Before taking history and collecting blood samples, the purpose of study was explained to all the participants and written informed consent were obtained. Histories were taken on printed forms. A $5 \mathrm{ml}$ blood was collected from the brachial vein of 30 shoe making workers and 20 control people. Blood pressure and body temperature were recorded. $3 \mathrm{ml}$ blood was transferred to test tube containing heparin for complete blood profile. $2 \mathrm{ml}$ blood was transferred to falcon tube having no anticoagulant for the isolation of serum and the samples were then transferred to $\left(-20^{\circ} \mathrm{C}\right)$ a refrigerator for storage.

\subsection{Serum Isolation}

Test tubes were kept in a slanting position and transferred to other sterilized test tubes after the oozing out of serum. Serum was used for analysis of different blood chemicals. Shimadzu UV-Visible double beam spectrophotometer 1700 Pharma (Japan) and SYSMEX (Hematology Analyzer) KX-21(Japan) was used.

\subsection{Samples Analysis for Different Biochemical Parameters}

The biochemical parameters that were analyzed for both the workers and control group were 
glucose level, cholesterol level, triglycerides level, SGPT level, Alkaline phosphatase, creatinine, uric acid, LDL- Cholesterol and HDL- Cholesterol.

The glucose level was determined in the presence of glucose oxidase, formed when hydrogen peroxide reacts with phenol and 1-aminophenazone to give red violet colour as indicator (Barham et al., 1972 and Teuscher et al., 1971). The cholesterol was measured by using the procedure mentioned by Trinder et al., 1969 and Kaplan et al., 1989. The triglycerides were determined after the enzymatic hydrolysis with lipases. Indicator is quinonemine formed from hydrogen peroxide; 4-amino antipyrine and 4-chlorophenol under the catalytic influence of peroxidase (Schettler and Nossel 1975, Jacobs and VanDemark 1960). The CRESCENT Diagnostic kits (Saudi Arabia) were used for serum Glutamate Pyruvate Transaminase (SGPT) determination. This is based on colorimetric determination of GPT activity. Alkaline Phosphatase (ALP) was measured by using kinetic photometric test, optimized standard method according to the German Society of Clinical Chemistry (DGKC). Creatinine was estimated by kinetic method without deproteinisation-Jaffe reaction using CRESCENT diagnostics kits (Saudi Arabia). Creatinine reacts with alkaline picrate to produce a reddish-orange color. The intensity of this colour at $490 \mathrm{~nm}$ is directly proportional to the creatinine concentration. Uric acid was estimated by enzymatic colorimetric test using HUMAN diagnostic kit (Germany). Uricase catalyzes the oxidation of uric acid to allantoin $\mathrm{H}_{2} \mathrm{O}_{2}$. In the presence of peroxidase (POD), $\mathrm{H}_{2} \mathrm{O}_{2}$ react with 4-aminoantipyrine (4-AA) and 3, 5, dichloro-2-hydrroxybenzenesulphonate (DHBS) to form a quinoneimine dye, the concentration of which at $520 \mathrm{~nm}$ is directly proportional to the uric acid concentration. High Density Lipoproteins (HDL) and Low Density Lipoprotein (LDL)-Cholesterol contents were determined enzymatically according to the method provided with Dia Sys cholesterol FS, kit (Germany).

\subsection{Blood Profile}

An automatic digital machine (Sysmex KX-21 Japan) was used for blood profiling. Heparinized blood was used for the complete blood count. Hemoglobin (Hb \%), Total Red Blood Cell Count (TRBC), Hematocrit Value (HCT), Mean Corpuscular Volume (MCV), Mean Corpuscular Hemoglobin (MCH), Mean Corpuscular Hemoglobin Concentration (MCHC), Total Leukocyte Count (TLC), Platelets Count, Neutrophils, Lymphocytes, Eosinophils, and Monocytes were measured.

\subsection{Data Analysis}

The data obtained was statistically analyzed. Mean, Standard deviation, column statistics and row statistics were performed for each parameter. Graphpad Prism, Demo version 5.0 was used (www.graphpad.com).

\section{Results}

\subsection{History of Workers and Control}

To collect the specific information from workers as well as from control group, a questionnaire was formulated regarding their age and health status. The information collected is summarized 
in table 1 and 2.

Table 1 . History of Workers $(\mathrm{n}=30)$

\begin{tabular}{|l|l|l|l|l|l|l|}
\hline $\begin{array}{l}\text { Age group } \\
\text { (years) }\end{array}$ & $\begin{array}{l}\text { No. of } \\
\text { workers }\end{array}$ & $\begin{array}{l}\text { Marital } \\
\text { Status }\end{array}$ & $\begin{array}{l}\text { Exposure } \\
\text { time } \\
\text { (hours/day) }\end{array}$ & $\begin{array}{l}\text { Total } \\
\text { time } \\
\text { years })\end{array}$ & $\begin{array}{l}\text { Health problems } \\
\text { before the job }\end{array}$ & $\begin{array}{l}\text { Health } \\
\text { problems after } \\
\text { the job }\end{array}$ \\
\hline $18-24$ & 6 & Unmarried & 9 hours & 2 years & No specific & Joint pain \\
\hline $25-31$ & 14 & Married & 10 hours & 6 years & No specific & Depression \\
\hline $32-38$ & 4 & Married & 8 hours & 7 years & No specific & Allergy \\
\hline $39-45$ & 4 & Married & 7 hours & 8 years & No specific & $\begin{array}{l}\text { Joint pain, } \\
\text { allergy }\end{array}$ \\
\hline $46-52$ & 2 & Married & 6 hours & 10 years & No specific & $\begin{array}{l}\text { Depression, } \\
\text { Allergy, GIT* }\end{array}$ \\
\hline
\end{tabular}

$\mathrm{GIT}^{*}=$ Gastrointestinal tract

Table 2. History of Control $(n=20)$

\begin{tabular}{|l|l|l|l|l|}
\hline $\begin{array}{l}\text { Age group } \\
\text { (years) }\end{array}$ & No of workers & Marital status & Exposure time & Health problems \\
\hline $18-24$ & 4 & Unmarried & No exposure & No specific \\
\hline $25-31$ & 3 & Married & No exposure & No specific \\
\hline $32-38$ & 5 & Married & No exposure & No specific \\
\hline $39-45$ & 6 & Married & No exposure & No specific \\
\hline $46-52$ & 2 & Married & No exposure & No specific \\
\hline
\end{tabular}

\subsection{Blood Biochemical Parameters}

A $2 \mathrm{ml}$ blood sample was taken from both the workers and control group and was transferred to falcon tubes. After clotting of blood, serum oozed out and was transferred to other sterilized tubes for blood biochemical analysis.

All the serum samples were analyzed for determination of blood glucose level, blood cholesterol level, triglyceride level, SGPT, alkaline phosphatase, creatinine, uric acid, LDL cholesterol and HDL cholesterol.

\subsection{Blood Cholesterol Level}

Cholesterol is an essential structural component of mammalian cell membranes and an important component in the synthesis of steroid hormones, bile acids and several fat soluble vitamins (Leah 2009). About 20-25\% of the total daily cholesterol production occurs in the liver; intestines, adrenal glands and reproductive organs being other sites for cholesterol synthesis (Pearson et al 2004). The mean blood cholesterol level along with standard deviation for both shoe making workers and control are given in figure no 1 . In workers, the serum cholesterol level was $218 \pm 12 \mathrm{mg} / \mathrm{dl}$ with a range of 202 to $244 \mathrm{mg} / \mathrm{dl}$. In control, it was $159 \pm$ $29 \mathrm{mg} / \mathrm{dl}$ with a range of 102 to $197 \mathrm{mg} / \mathrm{dl}$. The result showed that there was significant increase $(\mathrm{P}<0.005)$ in serum cholesterol level due to exposure to certain glues and chemicals like benzene, toluene, xylene and n-hexane. 


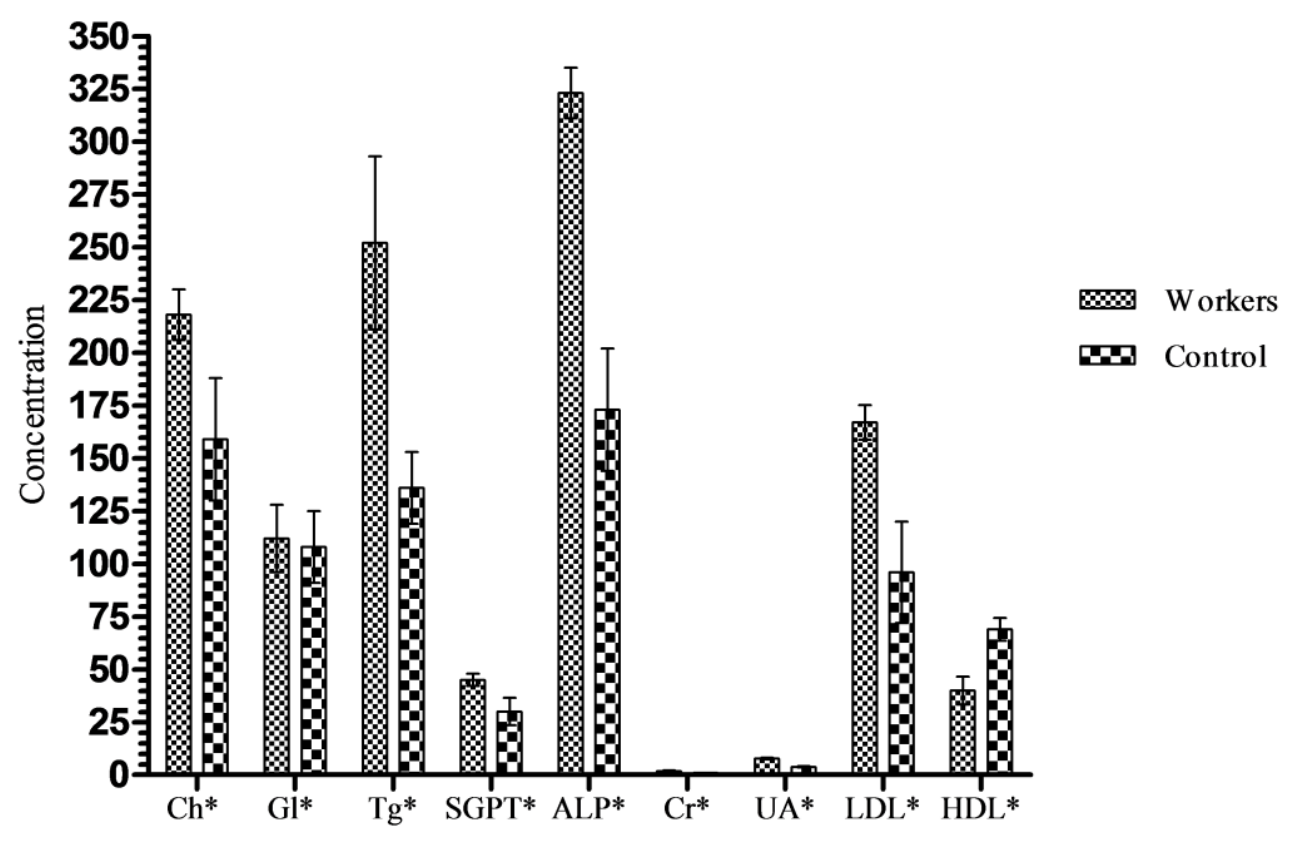

Figure 1. Blood biochemical parameters of shoe making workers and control

$\mathrm{SD}^{*}=$ Standard Deviation,SGPT*= Serum Glutamate Pyruvate Transaminase

$\mathrm{ALP}^{*}=$ Alkaline phosphatase, $\mathrm{LDL}^{*}=$ Low density lipoprotein,

HDL*= High density lipoprotein

\subsection{Blood Glucose Level}

Some of the glucose is directly utilized as a source of energy by brain cells, red blood cells and intestinal cell while the rest reaches muscle cells, liver and adipose tissue where it is stored as glycogen under the fatty influence of insulin (Fraser-Red and Bert 2009). The mean value of blood glucose level in workers was $11216 \mathrm{mg} / \mathrm{dl}$ with a range of 81 to $138 \mathrm{mg} / \mathrm{dl}$. The mean \pm standard deviation of glucose for control was $10817 \mathrm{mg} / \mathrm{dl}$ with a range of 82 to $136 \mathrm{mg} / \mathrm{dl}$ (Figure 1). There is no significance difference $(\mathrm{P}<0.005)$ between glucose level of workers and control. It was concluded that there was no significant effect of glues and organic solvents on glucose level of shoe making workers.

\subsection{Blood Triglyceride Level}

In human body, high level of triglyceride in the blood stream has been linked to atherosclerosis, and extends the risk of heart disease and stroke. The risk can be partly accounted for by a strong inverse relationship between triglyceride level and HDL- cholesterol level (American Heart Association 2013). The mean and standard deviation of both workers and controls has been shown in figure 1 . The mean blood triglyceride level along with standard deviation of shoe making workers was $252 \pm 41 \mathrm{mg} / \mathrm{dl}$ with a range of 206 to $350 \mathrm{mg} / \mathrm{dl}$. In control, it was $136 \pm$ $17 \mathrm{mg} / \mathrm{dl}$ with a range of 114 to $174 \mathrm{mg} / \mathrm{dl}$. The significant difference $(\mathrm{P}<0.005)$ between the triglyceride level of workers and control showed that shoe polish, organic solvents and glues 
had significant effects on the triglyceride level of shoe making workers.

\subsection{Serum Glutamate Pyruvate Transaminase (SGPT)}

SGPT (Serum Glutamate Pyruvate Transaminase) is a liver enzyme produced by liver cells (hepatocytes) and is specific for liver damage. Liver inflammation can occur due to drug/medication, fatty infiltration, alcohol, liver and bile duct diseases (Cabot 2006). Hepatocytes damage will cause elevation of SGPT due to leakage. This elevation of enzymes correlates with the number of damaged cells. Low level of GPT may indicate recovery or may indicate failing number of functional liver cells. Abrupt rise in SGPT indicates an acute process, while slow increase may show bile duct obstruction (Fleming 2006). The mean SGPT level in workers was $45 \pm 2.9 \mathrm{IU} / \mathrm{L}$ with a range of 39 to $53 \mathrm{IU} / \mathrm{L}$, and in control was $30 \pm 6.5 \mathrm{IU} / \mathrm{L}$ and the range was 16 to 40 IU/L (Figure 1$)$. The results showed significant increase $(\mathrm{P}<0.005)$ in SGPT level of workers.

\subsection{Alkaline Phosphatase (ALP) Level}

Alkaline phosphatase in healthy adults mainly derives from liver, bones and in lesser amount from intestine, kidneys, leukocytes and placenta (Friedman 1996). An increase in alkaline phosphatase level is frequently associated with a variety of diseases, such as intrahepatic cholestasis, extra hepatic bile obstruction, and hepatitis (Wiwanitkit 2001). In shoe making workers, the serum ALP level was $323 \pm 12 \mathrm{IU} / \mathrm{L}$ with a range of 309 to $359 \mathrm{IU} / \mathrm{L}$. In control, it was $173 \pm 29 \mathrm{U} / \mathrm{L}$ with a range of 103 to $229 \mathrm{IU} / \mathrm{L}$ (Figure 1). The results showed that there was significant increase $(\mathrm{P}<0.005)$ in ALP level in shoe making workers. The reason may be the exposure to benzene, toluene, xylene etc which are used as adhesives and other glues by shoe making workers.

\subsection{Blood Creatinine Level}

Serum urea and creatinine level are important indices for evaluation of chemicals effects on the kidneys. As the kidneys become impaired, the creatinine level in blood will rise. The presence of high concentration of urea and creatinine in the blood suggests the inability of the kidney to excrete these products (Ovuru et al 2004). The blood creatinine level of workers was $1.8 \pm 0.21$ $\mathrm{mg} / \mathrm{dl}$ with a range of 1.5 to $2.4 \mathrm{mg} / \mathrm{dl}$. In control, the creatinine level was $0.83 \pm 0.14 \mathrm{mg} / \mathrm{dl}$ and the range was 0.60 to $1.0 \mathrm{mg} / \mathrm{dl}$ (Figure 1). The difference $(\mathrm{P}<0.005)$ between the values of workers and control showed that chemicals used in shoe making have significant effect on kidney filtration of shoe making workers.

\subsection{Blood Uric Acid Level}

Uric acid is present in extremely small amount in human urine but constitute a large part of body waste matter of birds and reptiles. Sometime it accumulates as the human kidney stones or deposited upon bones in the form of urates (Sulemanet al 2011). The uric acid level of shoe making workers was $7.7 \pm 0.37 \mathrm{mg} / \mathrm{dl}$ with a range of 7.1 to $8.5 \mathrm{mg} / \mathrm{dl}$ and in control was $3.8 \pm$ $0.22 \mathrm{mg} / \mathrm{dl}$ with a range of 3.4 to $4.2 \mathrm{mg} / \mathrm{dl}$ (Figure 1). There was significant increase $(\mathrm{P}<0.005)$ in the uric acid level of workers as compared to control which showed that organic solvents, certain glues and adhesives used by shoe making workers affected the uric acid levels. 


\section{$\Lambda$ Macrothink}

\subsection{Blood Low Density Lipoprotein (LDL)}

Low density lipoprotein (LDL) and high density lipoprotein (HDL) are the two major classes of lipoprotein. They have different effects on the risk of coronary heart disease (CHD). High concentrations of LDL are atherogenic while high concentrations of HDL are negatively associated with the risk of CHD. It should be realized that some people have high total cholesterol concentrations, due to high HDL levels. Therefore the total cholesterol to HDL cholesterol might be the most efficient predictor for the risk of CHD (Kannel and Wilson 1992). The mean and standard deviation of LDL of shoe making workers was $167 \pm 8.2 \mathrm{mg} / \mathrm{dl}$ with a range of 155 to $181 \mathrm{mg} / \mathrm{dl}$ and that of control was $96 \pm 24 \mathrm{mg} / \mathrm{dl}$ with a range of 45 to $131 \mathrm{mg} / \mathrm{dl}$ (Figure 1). Results showed that there was significant increase $(\mathrm{P}<0.005)$ in LDL in shoe making workers as compared to control.

\subsection{Blood High Density Lipoprotein (HDL)}

The mean and standard deviation of HDL of workers was $40 \pm 6.6 \mathrm{mg} / \mathrm{dl}$ with a range of 30 to $57 \mathrm{mg} / \mathrm{dl}$. The mean and standard deviation of control was $69 \pm 5.4 \mathrm{mg} / \mathrm{dl}$ with a range of 62 to $86 \mathrm{mg} / \mathrm{dl}$ (Figure 1). The results showed that there was a significant decrease $(\mathrm{P}<0.005)$ in $\mathrm{HDL}$ level of shoe making workers.

\subsection{Blood Profile}

$3 \mathrm{ml}$ of blood sample each was transferred to heparinized tubes for the analysis of complete blood profile; hemoglobin (Hb), total red blood cell count (TRBC), hematocrit value (HCT), mean corpuscular volume (MCV), mean corpuscular hemoglobin $(\mathrm{MCH})$, mean corpuscular hemoglobin concentration (MCHC), total leukocyte count (TLC) and differential leukocyte count (DLC). Complete blood profile was analyzed for shoe making workers and also for control (Figure 2).

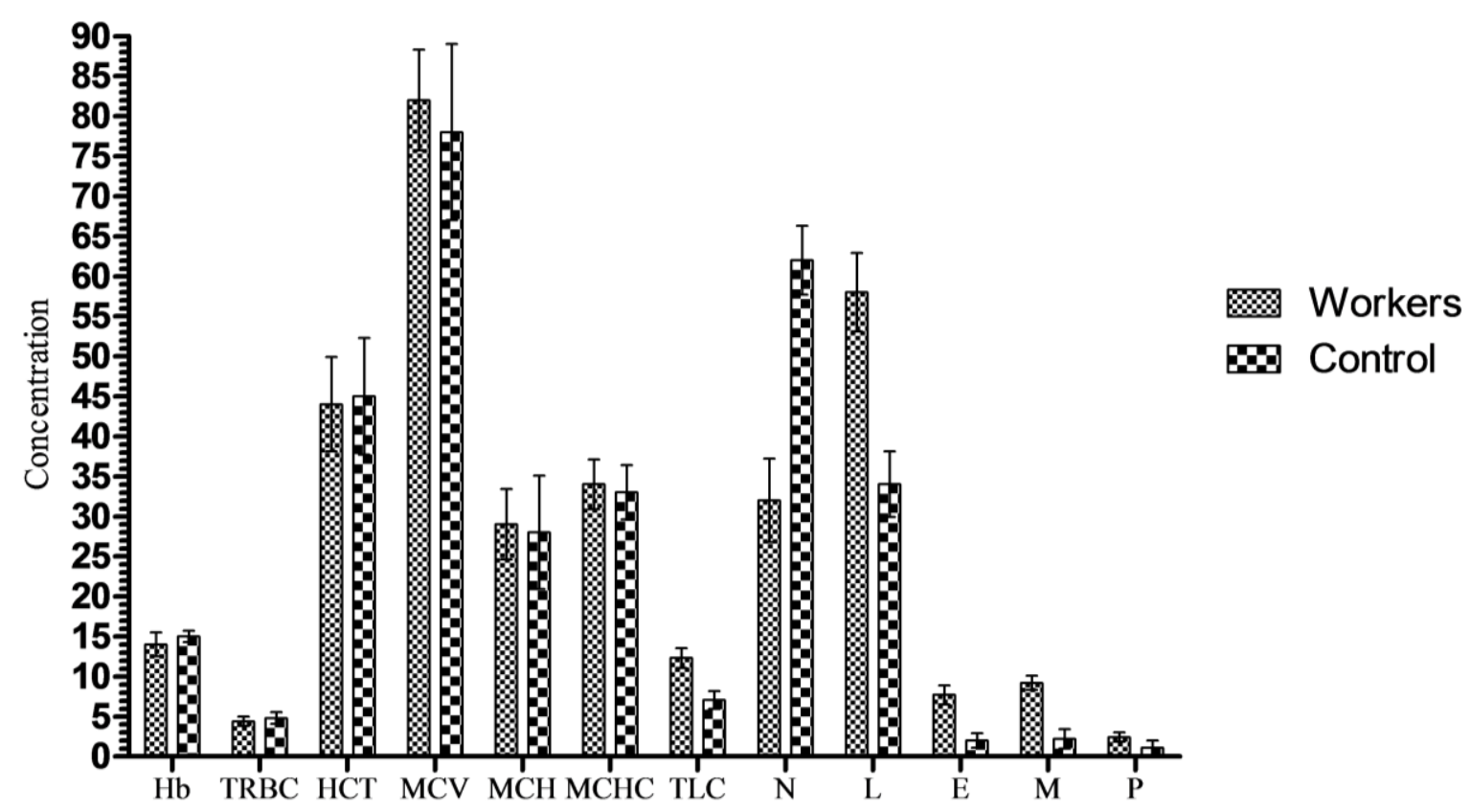

Figure 2. Complete blood profile of shoe making workers and control 
$\mathrm{SD}^{*}=$ standard Deviation, $\mathrm{RBC}^{*}=$ Red Blood Cells, $\mathrm{Hb}^{*}=$ Hemoglobin, $\mathrm{MCV}^{*}=$ Mean Cell Volume,

$\mathrm{MCH}^{*}=$ Mean Corpuscular Hemoglobin, HCT *= Hematocrit, $\quad$ TLC $*=$ Total Leukocyte Count,

$\mathrm{MCHC}^{*}=$ Mean Cell Hemoglobin Concentration

\subsection{Hemoglobin $(\mathrm{Hb})$ Level}

Hemoglobin is a chromoprotein forming 95\% of the dry weight of RBC and 30-34\% of wet weight. The main function of hemoglobin is the transport of respiratory gases. The normal hemoglobin $(\mathrm{Hb})$ contents in blood are 14-16 gm\%. In adult male, it is $15 \mathrm{gm} \%$ while in adult female; it is $14.5 \mathrm{gm} \%$ (Semibulingam and Perma 2006). The mean hemoglobin level and standard deviation of workers was $14 \pm 1.5 \mathrm{gm} / \mathrm{dl}$ having a range of 11 to $16 \mathrm{gm} / \mathrm{dl}$. In control, it was $15 \pm 0.70 \mathrm{gm} / \mathrm{dl}$ with a range 14 to $16 \mathrm{mg} / \mathrm{dl}$ (Figure 2). There was no significant difference $(\mathrm{P}<0.005)$ in the hemoglobin level of workers as compared to control.

\subsection{Total Red Blood Cells (TRBC) Count}

The mean and standard deviation of TRBC of both shoe making workers and control has been given in figure no 2 . The TRBC count in workers was $4.4 \pm 0.58 \mathrm{million} / \mathrm{cmm}$ on an average and a range of 3.1 to 5.6 million/cmm. The mean TRBC count in control was $4.8 \pm 0.74$ million/cmm with a range of 3.3 to 6.0 million/ $\mathrm{cmm}$. There was no significant difference $(\mathrm{P}<0.005)$ in TRBC count of workers and control.

\subsection{Hematocrit (HCT) Value}

The volume of red blood cells expressed in percentage is called the hematocrit value or packed cell volume (PCV). When the blood containing certain anticoagulant present in the hematocrit tube is centrifuged at a speed of 3000 revolution per minute for 30 minutes, the RBCs will settle down at the bottom and form $45 \%$ of the total blood while $55 \%$ will be the clear plasma (Semibulingam and Perma 2006). The HCT value of workers and control has been shown in figure 2. The mean and standard deviation of HCT value in shoe making workers was $44 \pm$ $5.9 \%$ with a range of 33 to $55 \%$ and that in control was $45 \pm 7.3 \%$ and its range was 28 to $61 \%$. The results showed that there was no significant difference $(\mathrm{P}<0.005)$ in the HCT value of both shoe making workers and control.

\subsection{Mean Corpuscular Volume (MCV)}

The average volume of a single RBC is known as MCV and its unit is cubic micron (cu. $\mu$ ). The normal $\mathrm{MCV}$ is $90 \mathrm{cu} . \mu$ (78 to $90 \mathrm{cu} . \mu$ ). In megaloblastic anemia and in pernicious anemia, RBCs are macrolytic in nature, so MCV is more while it is less in microlytic anemia (Semibulingam and Perma 2006). The mean and standard deviation of MCV in workers was 82 \pm 6.3 cu. $\mu$ with a range of 62 to 92 cu. $\mu$ and the in control was $78 \pm 11$ cu. $\mu$ with a range of 52 to 91 cu. $\mu$ (Figure 2$)$. The results showed that there was no significant difference $(\mathrm{P}<0.005)$ in the MCV level of both workers and control.

\subsection{Mean Corpuscular Hemoglobin (MCH)}

$\mathrm{MCH}$ is the amount of hemoglobin present in one RBC and it is expressed in Pico gram (pg). In 
pernicious and megaloblastic anemia it decreases or remains normal, in which RBCs are macrolytic and normochromic or hypochromic (Semibulingam and Perma 2006). The mean $\mathrm{MCH}$ in workers was $29 \pm 4.4 \mathrm{pg}$ and the range was 19 to $39 \mathrm{pg}$. In control, it was $28 \pm 7.1 \mathrm{pg}$ having the range of 18 to $52 \mathrm{pg}$ (Figure 2$)$. There was no significant difference $(\mathrm{P}<0.005)$ in $\mathrm{MCH}$ of both workers and control.

\subsection{Mean Cell Hemoglobin Concentration (MCHC)}

MCHC is the amount of hemoglobin expressed in relation to the volume of one RBC and expressed as percentage. The normal value of MCHC is $30 \%$ (30 to 38\%). This is the most absolute value in the diagnosis of anemia and decreases in iron deficiency anemia in which RBCs are hypochromic and microlytic (Semibulingam and Perma 2006). The mean and standard deviation of MCHC in workers was $34 \pm 3.1 \%$ and a range of 26 to $39 \%$ and in control was $33 \pm 3.4 \%$ with a range of 23 to $37 \%$ (Figure 2). The result showed that there was no significant difference $(\mathrm{P}<0.005)$ in the $\mathrm{MCHC}$ of workers and control.

\subsection{Total Leukocyte Count (TLC)}

About 7000 white blood cells are present per microliter of blood in a healthy human adult. There are six types of white blood cells and these are neutrophils, eosinophil, basophils, monocytes, lymphocytes and plasma cells (Guyton and Hall 2006). The mean and standard deviation of TLC in both the workers and control have been given in figure 2 . The mean TLC and standard deviation in shoe making workers was $12301 \pm 1233 / \mathrm{cmm}$ with a range of 10400 to $15000 / \mathrm{cmm}$. The mean TLC and standard deviation in control was $7085 \pm 1133 / \mathrm{cmm}$ with a range of 4850 to $8800 / \mathrm{cmm}$. There was a significant difference $(\mathrm{P}<0.005)$ in the TLC of both the groups.

\subsection{Neutrophil count}

Neutrophils play an important role in the body's defense mechanism and provide the first line of defense against the microorganisms. The granules of neutrophils contain enzymes (proteases, myeloperoxidases, elastases and metalloproteinases) which destroy the microorganisms (Semibulingam and Perma 2006). The mean and standard deviation of workers was $32 \pm 5.2 \%$ with a range of 22 to $40 \%$. The mean and standard deviation of neutrophils in control was $62 \pm$ $4.3 \%$ and its range was 54 to $70 \%$ (Figure 2 ). There was significant decrease $(\mathrm{P}<0.005)$ in the neutrophils count of shoe making workers than that of control.

\subsection{Lymphocytes Count}

The lymphocytes are a group of white blood cells and play an important role in immunity. On the basis of their size, they are divided into small and large lymphocytes and on the basis of function they are divided into T- lymphocytes and B-lymphocytes (Semibulingam and Perma 2006). The mean along with standard deviation of lymphocytes count in shoe making workers and control has been given in figure no 2 . The mean \pm standard deviation of workers was $58 \pm$ $4.9 \%$ with a range of 49 to $66 \%$ and that of control was $34 \pm 4.1 \%$ with a range of 26 to $40 \%$. The results showed that there was a significant increase $(\mathrm{P}<0.005)$ in the lymphocyte count in workers as compared to control. 


\subsection{Eosinophil Count}

The eosinophils play an important role in the defense mechanism of the body and their count increases during allergic conditions and parasitic reaction. They are responsible for disintegration, detoxification and removal of foreign particles (Semibulingam and Perma 2006). The mean and standard deviation of eosinophil in workers was $7.7 \pm 1.2 \%$ with a range of 6 to $11 \%$ and in control was $2 \pm 0.92 \%$ with a range of 1 to $4 \%$ (Figure 2). There was significant difference $(\mathrm{P}<0.005)$ in the values of both shoe making workers and control.

\subsection{Monocyte Count}

These are the largest leukocytes and move freely through all tissues of the body and play an important role in the defense of the body (Semibulingam and Perma 2006). The mean and standard deviation of monocytes in shoe making workers was $9.2 \pm 0.88 \%$ with a range of 7.3 to $11 \%$ and in control, it was $2.2 \pm 1.2 \%$ with a range of 1 to $4 \%$ (Figure 2). The results showed that there was significant increase $(\mathrm{P}<0.005)$ in the monocyte count of workers as compared to control.

\subsection{Platelets Count}

Platelets are considered to be the fragments of cytoplasm. Platelets are formed by megakaryocytes in the bone marrow. The normal platelet count is about 2, 50,000 cubic mm of blood and they help in blood clotting (Semibulingam and Perma 2006). The mean and standard deviation of platelets count in both the shoe making workers and control has been given in figure no 2. In workers, the mean count and standard deviation was $108103 \pm 9331 / \mathrm{cmm}$ with a range of 98000 to $130000 / \mathrm{cmm}$ and in control, it was $242976 \pm 57987 / \mathrm{cmm}$ with a range of 181900 to $380000 / \mathrm{cmm}$. There was significant difference $(\mathrm{P}<0.005)$ in platelets of workers and that of control.

\section{Discussion}

To collect the history from workers as well as control, data was collected on printed form regarding the age, and health status. The workers were engaged for different working hours per day at shops and most of the workers recently joined this occupation. There was joint pain, depression, asthma, contact dermatitis and gastrointestinal abnormalities. There were no such complications present in control group. Various research workers have identified different types of effects on workers and these were local irritation, typically to the eyes and the nose (Ukai et al 1994), dizziness and floating sensations (Ukai et al 1993), reproductive problems (Fiedler and Lerman 2007), neurological and psychological disorders (Elci et al 2007), and musculoskeletal system, contact dermatitis, chronic pulmonary diseases and damage of peripheral nerves in solvent-exposed workers (Szadkowska-Stańczyk et al 2003). These results concluded that chemicals in adhesive reagents used in shoe making have severe ill effect on the health of the workers.

The results of present study showed that there was significant increase in serum cholesterol level due to exposure to certain glues and chemicals like benzene, toluene, xylene and n-hexane in workers as compared to control. Khan and Yusufi 2009 observed that nephrotoxic 
effect of benzene was manifested by increase blood urea nitrogen, serum creatinine and cholesterol levels. Takahashi et al 1988 studied changes of plasma lipids, free fatty acid, and blood glucose in male rabbits after toluene administration. Initially, plasma cholesterol was virtually unchanged, but the cholesterol level increased slowly after $6 \mathrm{~h}$. It showed that exposure to organic chemicals at working place has an ill effect on the cholesterol level and these workers are at more risk to have cardiovascular problems. There was no significant difference between glucose level of workers and control as mentioned in results. It has been concluded that there was no significant effect of adhesive glues and organic solvents on glucose level of shoe makers. Sukhodub 1997 found an increase in glucose concentration in the blood serum of 24-month old rats after 2-days benzene treatment. Takahashi et al 1988 reported initial hyperglycemia and then hypoglycemia in male rabbits, after toluene administration. The reason for this deviation may be the difference in the concentrations of benzene and other adhesive organic solvents, differences in durations of exposure and differences in the experimental subjects. There was significant increase in blood triglyceride levels of shoe making workers as compared to control. The differences between the blood triglyceride levels of workers and control showed that shoe polish, organic solvents and glues have significant effect on the triglyceride level of shoe making workers. Stumph et al 1985 measured blood and brain toluene concentration and circulating triglyceride levels in male Sprague-Dawley rats after exposure to $2500 \mathrm{ppm}$ toluene and found an increase in circulating triglyceride levels. Takahashi et al 1988 observed high blood triglyceride level at and after 2 hours of toluene administeration in male rabbits. The hypertriglyceridemia observed may have some adverse effects on heart function. The results in the present study showed an increase in SGPT level of workers as compared to control. Ayan et al 2012 investigated the acute toxic effects of high-dose toluene and its mechanisms on the liver tissue of toluene-treated rats. The level of plasma transaminase was found to be increased in toluene administered rats. Tas et al 2011 mentioned the harmful effects of toluene inhalation in the liver of rats and possible protective effects of melatonin on these detrimental effects. Toluene inhalation significantly increased serum ALT and AST, and decreased serum albumin, but did not affect serum ALP and total bilirubin levels. Dere et al 2003 also found same results by investigating the effects of benzene, an occupational and environmental toxicant, on different enzymes of liver and kidney of rats. Kinght et al 1991 reported an increased level of serum transaminases and gama glutamyl transpeptidase (GGT) in workers in the printing industry exposed to toluene via the respiratory route. Same results have also been reported by Ann et al 2001 and Hussein et al 2008 that studied the workers exposed to organic solvents and having increased levels of liver transaminases and GGT, which indicate hepatic necrosis and cholestasis. It was concluded that organic chemicals in workshops have toxic effect on liver and lead to increase in liver enzymes. In the present study, there was a significant increase in ALP level in shoe makers. The reason might be the exposure of shoe makers to benzene, toluene, and xylene used as adhesive and other glues. According to NIOSH, 4.8 million workers are exposed to toluene, and 140,000 workers are exposed to xylene (Rosenberg and Katz 2007). Mohammadi et al 2010 mentioned that mean plasma ALP level in the case group was significantly higher than in the control group. Brodkin et al. 2001 did two cross-sectional studies in workers exposed to lower levels of styrene and found increased levels of direct bilirubin and alkaline phosphatase compared with 
the control groups. Warnes et al 2000 and Xiao and Levin 2000 have also reported that the additive effect of a mixture of organic solvents causes increased hepatotoxicity. Results of Uuksulainen et al 2002 are not in deviation from results of present study as there were no differences in the hepatic enzyme levels between the workers exposed to a mixture of organic solvents in shoe repair work and that in control. Pool and Orono 2001 studied workers occupationally exposed to mixed organic solvents in the petrochemical industry and found no differences in the levels of hepatic enzymes compared to the control group. Todd et al 2008 stated that there were no toxic effects of mixed organic solvents on liver. Tas et al 2011 investigated the harmful effects of toluene inhalation in the liver of rats and found no effect on serum ALP and total bilirubin levels. The reason for these deviations may be due to differences in samples size, experimental design, types of the solvents studied, and exposure intensity and also differences in diagnostic procedures. From the present study it has been concluded that the organic chemicals that are used in shoe making industry has toxic effect on liver. There was significant increase in creatinine level of workers as compared to control. The results suggested that chemicals used in shoe making have also an impact on kidney function of shoe makers. Khan and Yusufi 2009 determined multifaceted effects of long term benzene administration on various enzymes involved in carbohydrate metabolism, brush border membranes (BBM) and oxidative stress and found a significant increase in serum creatinine, BUN, serum cholesterol indicating significant damage to the kidney accompanied by increase in serum phospholipids and inorganic phosphate. González-Yebra et al 2006 documented that toluene may be a factor associated with the presence of renal damage in exposed shoe workers. Pai et al 1998 also concluded that toluene and hexane have toxic effects on kidneys of the paint sprayers in a car manufacturing plant where personal protective equipment was widely used. A significant number of sprayers had elevated levels of serum creatinine. These organic chemicals also lead to damage. There was a significant increase in the uric acid level of shoe making workers as compared to the control group. It showed that organic solvents and adhesives have toxic effect on uric acid level in blood. The reason may be over production by liver or poor elimination of uric acid by kidneys. No reported data is available on this parameter. The LDL level for both the workers and control was analyzed and results showed that there was significant increase in LDL in shoe making workers as compared to control. There was also a significant decrease in HDL level of shoe making workers. It has been concluded that the organic solvents and adhesives affected the LDL and HDL levels.

Complete blood profile for the both the shoe makers and control group has been made in present study. The parameters have been discussed as under;

The results showed that there was no significant difference in the hemoglobin level of workers as compared to control. Pesatori et al 2009 evaluated hematological outcomes (WBC, neutrophils, lymphocytes, monocytes, eosinophils, basophils, RBC, Hb, HCT MCV, platelets and MPV) in a population of 153 Bulgarian petrochemical workers exposed to benzene (range 0.01-23.9 ppm) and 50 unexposed subjects. No dose-response effect was observed for most of the examined hematological outcomes. Collins et al 1997 concluded that risk of lymphopenia and other early indicators of hematotoxicity are not increased among workers in the study who were exposed to low levels of benzene. Andrzejak et al 1992 assessed the general and 
toxicological status of footwear factory workers exposed to toluene, benzene and trace amounts of chromium. There was little effect of aromatic hydrocarbons on hematopoiesis. Bogadi-Sare et al 1995 studied hematotoxicity in female workers exposed to low benzene concentrations. Hemoglobin level and mean corpuscular hemoglobin concentrations were significantly lower in the shoemaking workers than in controls. Uzma et al 2008 investigated the toxic effect of chronic exposure of benzene and carbon monoxide in petrol filling workers on blood parameters, thyroid and respiratory functions. A significant increase in hemoglobin (>16 mg \%) was observed in workers with longer period of exposure when compared with the control subjects. The reason for this deviation might be the exposure to different constituents (mainly $\mathrm{CO}$, as it is not frequently present in shoe making workshop as compared to that of petrol pumps) in the environment of petrol pump as compared to that of shoe making workshop, duration of exposure and the differences in techniques through which the blood has been analyzed. The results for TRBC count for both the worker and the control groups showed no significant difference. It suggested that there was no toxic effect of organic solvents and adhesive on TRBC count in shoe makers. Pesatori et al 2009 evaluated hematological outcomes and observed no dose-response effect for most of the examined hematological outcomes. Collins et al 1997 found no increase in the prevalence of lymphopenia among benzene-exposed workers. Tsai et al 1983 reported no adverse hematologic effects in refinery workers exposed to low levels of benzene (less than $1 \mathrm{ppm}$ ) for 1 to 21 years. Uzma et al 2008 found a significant increase in red blood cells in workers with longer period of exposure when compared with the control subjects. The decrease in red blood cells have been found by Rothman et al 1996 in a cross-sectional study of 44 workers heavily exposed to benzene as an 8-hr time-weighted average and 44 age and gender-matched unexposed controls from Shanghai, China. Kipen et al 1989 observed significant decreases in leukocyte and erythrocyte counts and hemoglobin during the years of highest exposure. The reason for this deviation may be the differences in the working environment places, the toxicants concentrations in workshops, and duration of exposure of the workers to these toxicants. There was no significant difference in the HCT level of both shoe makers and control. Pesatori et al 2009 observed no dose-response effect in a population of 153 Bulgarian petrochemical workers exposed to benzene and 50 unexposed subjects. Rothman et al 1996 compared hematologic outcomes in 44 workers heavily exposed to benzene and unexposed controls from Shanghai, China and found reduction in hematologic parameters. The reason of deviation might be due to high exposure of toxicants, and difference in age of the subjects. The MCV in shoe makers and control was determined and results showed that there was no difference in the MCV of both workers and control. Pesatori et al 2009 and Collins et al 1997 found similar results for MCV. An increase in MCV was recorded by Fishbeck et al 1978 and also when exposure ceased off then the MCV gained the normal value. Bogadi-Sare et al 1995 investigated hematotoxicity in female workers exposed to low benzene concentrations and found high MCV in the shoemaking workers than in controls. An increase in MCV was found by Rothman et al 1996 after comparing hematologic outcomes in a cross-sectional study of 44 workers heavily exposed to benzene as an 8-hr time-weighted average and 44 age and gender-matched unexposed controls from Shanghai, China. There was no significant difference in mean corpuscular hemoglobin of workers and that of control. It has been concluded that chemicals 
used in shoe making have no any effect on $\mathrm{MCH}$. An increase in $\mathrm{MCH}$ was observed by Bogadi-Sare et al 1995 that investigated hematotoxicity in female workers exposed to benzene concentrations. The MCH was significantly lower in the shoemaking workers than in controls. In the subgroup of shoemaking workers exposed to benzene concentrations of $5 \mathrm{ppm}$ or lower, no differences in hematological parameters were found. The reason of the deviation may be the toxicants concentrations in workplaces. There was no significant difference in the MCHC of workers and that of control. Bogadi-Sare et al 2003 found the difference in MCHC in benzene-exposed workers and in control by analyzing the hematological, immunological, and cytogenetic assay results. MCHC was lower in the shoe workers than in controls (Bogadi-Sare et al 1997). Moszczyński and Lisiewicz 1983 studied 106 workers occupationally exposed to benzene, toluene and xylene and observed a decrease in MCHC. There was significant increase in TLC of shoe making workers as compared to that of control. No reported data was found on this parameter.The results for neutrophil count showed a significant decrease in its number as compared to control. Qu et al 2002 examined hematological findings in Tianjin, China and observed significant decrease in red blood cells (RBC), white blood cells (WBC), and neutrophils and correlated with both personal benzene exposures and levels of urinary metabolites. Pesatori et al 2009 found no effect on neutrophil count. The results for lymphocyte count showed a significant increase in shoe making workers as compared to control. Doskin (1971) observed lymphocytosis in workers exposed to 3 to $13 \mathrm{ppm}$ benzene for 1 to 3 years. Swaen et al 2010 examined hematological effects at low benzene exposure levels in an occupational setting and lymphocyte counts for the exposed and non-exposed group were similar. Aoyama 1986 examined immunotoxicity of benzene, and found that effects on humoral and cell-mediated immune responses are a result of the selective toxicity of benzene on B lymphocytes and suppressor T cells. Reason for deviation might be the differences in durations of exposure and also in exposure levels to the toxicants, and also differences in experimental subjects. There was significant difference in eosinophil count among shoe making workers and control. Uzma et al 2008 investigated effect of chronic exposure to benzene and carbon monoxide in petrol filling workers. White blood cell count except eosinophil and platelets were significantly lower in workers compared to controls. Aksoy et al 1971 studied hematological parameters in workers, 95\% of whom worked with solvents containing benzene in small shops manufacturing shoes under unhygienic conditions. It was concluded that benzene exerts its harmful effect, primarily on the leucocytes, with eosinophilia and basophilia and thrombocytopenia, and finally pancytopenia. The results showed a significant increase in the monocyte count of workers as compared to control. Moszczynski and Lisiewicz (1982) performed quantitative evaluation of the white blood cell and the platelet system and found an increased count of monocytes in the peripheral blood. A significant decrease in platelet count was observed in shoe making workers as compared to that of control. Andrzejak et al 1992 evaluated the general and toxicological status of footwear factory workers exposed to toluene, benzene and trace amounts of chromium and that three persons were affected with thrombocytopenia. Aksoy et al 1971 also found same results in 217 male Turkish workers exposed to a maximum of $210 \mathrm{ppm}$ benzene for a period of 4 months to 17 years and found thrombocytopenia. Pesatori et al 2009 evaluated hematological outcomes in a population of 153 Bulgarian petrochemical workers exposed to benzene and 50 unexposed subjects. There 
was no effect on platelets. Uzma et al 2008 sorted out the adverse effect of chronic exposure to benzene and carbon monoxide and found that white blood cell count except eosinophil and platelets were significantly lower in workers compared to controls. Collins et al 1997 found no increase in the prevalence of lymphopenia among benzene-exposed workers. No ill effect was observed on platelets count among the workers. The reason for the deviation from the present results may be the differences in age, gender, habits, and in environment where the studies have been carried out and also in diagnostic procedures.

\section{Conclusions and recommendations}

The present study focuses on the health effects of shoe making workers that are exposed to hazardous substances during the processing and repairing of shoes. Different organic solvents and adhesive glues that contain benzene, toluene, xylene and hexanes are used during making and repair. Workers are persistently exposed to these toxic substances and are unaware of its hazardous effects. The workers were affected with asthma, contact dermatitis, depression, joint pain, and gastrointestinal abnormalities. The problems were more severe in the workers that were engaged since long time in this occupation as compared to newly engaged ones. The conditions of workshops were very poor and unhygienic. No gloves or masks were being used to protect the skin from direct contact or to prevent the inhalation of these chemicals. These results suggest that these workers are at more risk to liver and cardiovascular problems as well as lung abnormalities. There is an urgent need to study more deeply on large populations to check the effects of exposure to the chemicals used in shoe making workshops.

\section{References}

Aksoy, M., Dinçol, K., Akgün, T., Erdem, S., \& Dinçol, G. (1971). Haematological effects of chronic benzene poisoning in 217 workers. British Journal of Industrial Medicine 28, 296-302. PMC1069505

Alkan, A., Kutlu, R., Hallac, T., Sigirci, A., Emul, M., Pala, N., Altinok, T., Aslan, M., Sarac, K., \& Ozcan, C. (2004). Occupational prolonged organic solvent exposure in shoemakers, brain MR spectroscopy findings. Magnetic Resonance Imaging, 22(5), 707-713. PMID: 15172065. http://dx.doi.org/10.1016/j.mri.2004.01.070

American Heart Association (2013) What Your Cholesterol Levels Mean, http://www.heart.org/HEARTORG/Conditions/Cholesterol/AboutCholesterol/WhatYourChol esterolLevelsMeanUCM305562_Article.jsp. Accessed on $12^{\text {th }}$ February, 2013

Andrzejak , R., Tomczyk J., Antonowicz , J., Lewczuk, E., Beck, B., \& Smolik , R. (1992). Prospective examinations concerning the effect of exposure to aromatic hydrocarbons on health status. Medycyna Pracy, 43(6), 531-5. PMID: 1296113.

Ann, C., Lee, K., Park, J., Jang, J., \& Kim, M. (2001). The Association of Exposure to Organic Solvents with liver function. Korean Journal of Occupational Environmental Medicine, 13, 64-74.

Aoyama, K. (1986). Effects of benzene inhalation on lymphocyte subpopulations and immune response in mice. Toxicology and Applied Pharmacology, 85(1), 92-101. PMID: 2941900. 
http://dx.doi.org/10.1016/0041-008X(86)90390-X

Armstrong, C. (1995). longitudinal neuropsychological effects of n-hexane exposure, Neurotoxic effects versus depression, Archives of Clinical Neuropsychology, 10(1), 1-19. http://dx.doi.org/10.1093/arclin/10.1.1

Ayan, M., Tas , U., Sogut , E., Kuloglu, T., Cayli, S., Kocaman, N., Karaca, Z. I., \& Sahin, M. (2012). The apoptotic effect of a high dose of toluene on liver tissue during the acute phase, an experimental study. Toxicology and Industrial Health, PMID: 22491721. http://dx.doi.org/10.1177/0748233712442731

Bae, H., Yang, W., \& Chung, M. (2004).Indoor and outdoor concentrations of RSP, NO2 and selected volatile organic compounds at 32 shoe stalls located near busy roadways in Seoul, Korea. Science of the Total Environment, 323(1-3), 99-105. PMID: 15081720. http://dx.doi.org/10.1016/j.scitotenv.2003.09.033

Bogadi-SareA., Turk, R., Karacic, V., Zavalic, M., \& Trutin-Ostovic, K. (1997). Red blood cell glycerol lysis and hematologic effects in occupational benzene exposure. Toxicology and Industrial Health, 13(4), 485-94. Pubmed: 9249930.

Bogadi-SareA., Turk, R., \& Zavalic, M. (1995). Medical surveillance studies of workers exposed to low level benzene. Arhiv Za Higijenu Rada I Toksikologiju, 46(4), 391-8. Pubmed: 8670009.

Bogadi-SareA., Zavalic, M., \& Turk, R. (2003). Utility of a routine medical surveillance program with benzene exposed workers. American Journal of Industrial Medicine, 44(5), 467-73. PubMed ID: 14571510. http://dx.doi.org/10.1002/ajim.10296

Braham, D., \& Trinder, P. (1972). Methods for determination of blood glucose level by spectrophotometer. Analyst, 97-142.

Brodkin, C., Moon, J., Camp, J., Echeverria, D., Redlich, C., Willson, R., \& Checkoway, H. (2001). Serum hepatic biochemical activity in two populations of styrene-exposed workers. Occupational Environmental Medicine, 58(2), 95-102. PMCID: PMC1740098. http://dx.doi.org/10.1136/oem.58.2.95

Cabot, S. (2006).The Healthy Liver \& Bowel Book; The liver. SCB International; Int edition ISBN-13: 978-0967398303, pp 98.

Collins, J. J., Ireland, B. K., Easterday, P. A., Nair, R. S., \& Braun, J. (1997). Evaluation of Lymphopenia Among Workers with Low-Level Benzene Exposure and the Utility of Routine Data Collection. Journal of Occupational \& Environmental Medicine, 39(3), 232-237. http://dx.doi.org/10.1097/00043764-199703000-00013

Dere, E., Gyborova, S., \& Aydin, H. (2003). The effect of benzene on serum hormones and the activity of some enzymes in different tissues of rats. Acta Veterinaria (Beograd), 53(2-3), 87-101. UDK 619:612.017.4

Doskin, V. A. (1971). Effect of age on the reaction to a combination of hydrocarbons. Hygiene 
and Sanitation, 36, 379-384.

Douidar, S. M., Shaver, C. S., \& Snodgrass, W. R. (1992). Hepatotoxicity from Hazardous chemicals. In: Sullivan JB, Krieger GR,eds. Hazardous Materials Toxicology, Clinical Principles of Environmental Health. Baltimore: Williams \& Wilkins, 109-123.

Elci, O. C., Yener, G., \& Ucku, R. (2007). Working conditions and related neuropsychiatric problems among shoemakers in Turkey, Do child workers differ from others? Indian Journal Occupational Environmental Medicine, 11(1), 9-14. PMID: 21957366 DOI: 10.4103/0019-5278.32458. http://dx.doi.org/10.4103/0019-5278.32458

Suleman, M., Khan, A. A., Hussain, Z., Zia, M. A., Roomi, S., Rashid, F., Iqbal, A., \& Ishaq, R. (2011).Effect of lead acetate administered orally at different dosage levels in broiler chicks. African Journal of Environmental Science and Technology, 5(12), 1017-1026. DOI: 10.5897/AJEST10.278 ISSN 1996-0786X. http://dx.doi.org/10.5897/AJEST10.278

Fiedler, N. L., \& Lerman, S. (2007). Organic Solvents and Fuels,in Environmental and Occupational Medicine. $4^{\text {th }}$ Edition, Rom W. N. (ed). Lippincott Williams \& Wilkins, 1103-1122.

Fishbeck, W. A., Townsend, J. C., \& Swank, M. G. (1978). Effect of chronic occupational exposure to measured concentrations of benzene. Journal of Occupational Medicine, 20(8), 539-542. PMID: 690738. http://dx.doi.org/10.1097/00043764-197808000-00005

Fleming, S. (2006). Siver disease. http://www.canin-epilepsy-guardian-angle.com/diagnostic_testing.html.

Fraser-Reid, B. (2009). Van’ t Hoff's Glucose.Chemicals and Engineering News,77(39), 8.

Friedman, L. S., Martin, P., \& Munoz, S. J. (1996). Liver function tests and the objective elevation of the patient with liver disease. In: Hepatology: a Textbook of Liver Disease (Editedby Zakim D,TD Boyer TD) Philadelphia, WB Saunders, pp 791-833.

Fu, H., Demers, P. A., Costantini, A. S., Winter, P., Colin, D., Kogevinas, M., \& Boffetta, P. (1996). Cancer mortality among shoe manufacturing workers, an analysis of two cohorts. Occupational and Environmental Medicine, 53(6), 394-8. PMID: 8758034 http://dx.doi.org/10.1136/oem.53.6.394

Gonzalez-Yebra, A. L., Kornhauser, C., Wrobel, K., Perez-Luque, E. L., Wrobel, K., \& Barbosa, G. (2006). Occupational exposure to toluene and its possible causative role in renal damage development in shoe workers. International Archives of Occupational and $\begin{array}{llll}\text { Environmental Health, 79(3), 259-64. } & \text { PMID: } & 16001213 .\end{array}$ http://dx.doi.org/10.1007/s00420-005-0001-7

Guyton, A. C., \& Hall, J. E. (2006). A text book of medical physiology, Edi $11^{\text {th }}$, Vol 1, Chapter 32 and 33, 419-437, Published by Elseveir

Hussein, A., Abdalla, M., Hussein, J., Shousha, W., \& Mohamed, A. (2008). Antioxidants in shoe-makers exposed to organic solvents. Journal of Applied Science and Research, 4, 
$1107-1117$.

Isci Sagligi Dernegi. (1992). (Association of Workers' Health), Working life of shoemakers. Isci Yasami 8, 20-21.

Jacobs, N. J., \& Vandemark, P. J. (1960). Archives Biochemistry Biophysics, 88, 250-55. http://dx.doi.org/10.1016/0003-9861(60)90230-7

James, E. F. (1996). The Extra Pharmacopeia. Thirty-first Edition, The Royal Pharmaceutical Society, London, 1404.

Jockel, K. H., Pohlabeln, H., Bolm-Audorff, U., Bruske-Hohlfeld, I., \& Wichmann, H. E. (2000). Lung cancer risk of workers in shoe manufacture and repair. American Journal of Industrial Medicine, $\quad 37, \quad 575-80$. http://dx.doi.org/10.1002/(SICI)1097-0274(200006)37:6<575::AID-AJIM1>3.0.CO;2-F

Kannel, W. B., \& Wilson, P. W. (1992). Efficacy of lipid profiles in prediction of coronary disease. Herican Heart Journal, $124, \quad 768-774$. http://dx.doi.org/10.1016/0002-8703(92)90288-7

Kaplan, L. A., \& Pesce, A. J. (1989). Procedures for the collection of arterial blood specimens: Approved Standard. Edi 3rd, Clinical Chemistry, Mooby Ed. NCCLS Document.

Khan, S., \& Yusufi, A. N. K. (2009). Effect of benzene on the enzymes of carbohydrate metabolism, brush border membrane (BBM) and oxidative stress in kidney and other rat tissues. Biology and Medicine, 1(2), 28-41. ISN: 09748369

Kinght, A., Pawscy, C., Aroney, R., Lawrence, J. R., Jones, D. B., \& Newland, R. C. (1991). Upholsteres glue associated with myocarditis, hepatitis, acute renal failure and lymphoma. The Medical Journal of Australia, 154(5), 360-362. PMID: 2017066

Kipen, H. M., Cody, R. P., \& Goldstein, B. D. (1989). Use of longitudinal analysis of peripheral blood counts to validate historical reconstructions of benzene exposure. EnvironmentalHealth Perspectives, 82, 199-206. PMID: 2792041. http://dx.doi.org/10.1289/ehp.8982199

Leah, E. (2009). Cholesterol, Lipidomics Gateway, 10, 1038. http://dx.doi.org/10.1038/lipidmaps.2009.3

Merker, G. H., Metzner, G., \& Raabe, F. (2006). T(H1)-directed modulation of in vitro cytokine production in human peripheral blood mononuclear cells by styrene-7.8-oxide.Toxicology Letters,160(2), 105-11. PMID： 16111840. http://dx.doi.org/10.1016/j.toxlet.2005.06.014

Mohammadi, S., Mehrparvar, A., Labbafinejad, Y., \& Attarchi. M. S. (2010). The effect of exposure to a mixture of organic solventson liver enzymes in an auto manufacturing plant. Journal of Public Health, http://dx.doi.org/10.1007/s10389-010-0340-z

Moszczyński, P., \& Lisiewicz, J. (1983). Hematological indices of peripheral blood in workers occupationally exposed to benzene, toluene and xylene. Zentralbl Bakteriol MikrobiolHyg B, 178(4), 329-39. PMID: 6670413. 
Natelson, E. A. (2007). Benzene-induced acute myeloid leukemia,S a clinician's perspective. American Journal of Hematology, 82(9), 826-30. PMID: 17506065. http://dx.doi.org/10.1002/ajh.20934

Ovuru, S. S., Berepubo, N. A., \& Nodu, M. B. (2004). Biochemical blood parameters in semi-adult rabbits experimentally fed crude oil contaminated diets. African Journal of Biotechnology, 3(6), 343-345.ISSN 1684-5315

Pai, P., Stevenson, A., Mason, H., \& Bell, G. M. (1998). Occupational hydrocarbon exposure and nephrotoxicity: a cohort study and literature review. Postgraduate Medical Journal, 74(870), 225-8. PMID: 9683976. http://dx.doi.org/10.1136/pgmj.74.870.225

Pearson, A., Budin, M., \& Brocks, J. J. (2004). Phylogenetic and biochemical evidence for sterol synthesis in the bacterium Gemmata obscuriglobus. Proceeding of the National Accademy of Science of the United State of America, 101(11), 3991.

Pesatori,A C., Garte, S., Popov, T., Georgieva, T., Panev, T., Bonzini, M., Consonni, D., Carugno, M., Goldstein, B. D., Taioli, E., Fontana, V., Stagi, E., Bertazzi, P. A., \& Merlo, D. F. (2009). Early effects of low benzene exposure on blood cell counts in Bulgarian petrochemical workers. Medicina Del Lavoro, 100(2), 83-90. PMID: 19382518.

Pool, F., \& Orono, A. (2001). Liver function of workers occupationally exposed to mixed organic solvents in a petrochemical industry. Investors Clinic, 42, 87-106.

Price, R. G. (2000). Urinalysis to exclude and monitor nephrotoxicity. Clinica Chimta Acta, 297(1), 173-182. PMID: 10841919. http://dx.doi.org/10.1016/S0009-8981(00)00244-8

Qu, Q., Shore, R., Li, G., Jin, X., Chen, L. C., Cohen, B., Melikian, A. A., Eastmond, D., Rappaport, S. M., Yin, S., Li, H., Waidyanatha, S., Li, Y., Mu, R., Zhang, X., \& Li, K.(2002). Hematological changes among Chinese workers with a broad range of benzene exposures. American Journal of Industrial Medicine, 42(4), 275-285. PMID: 12271475. http://dx.doi.org/10.1002/ajim.10121

Rana, S. V., \& Verma, Y. (2005). Biochemical toxicity of benzene.Journal of Environmental Biology, 26(2), 157-68, PMID 16161967.

Rosenberg, J., \& Katz, E. (2007). Solvents. In: Ladou J (ed) Current occupational and environmental medicine, 4th edn. McGraw Hill, USA, pp 499.

Rothman, N., Li, G. L., Dosemeci, M., Bechtold, W. E., Marti, G. E., Wang, Y. Z., Linet, M., Xi, L. Q., Lu, W., Smith, M. T., Titenko-Holland, N., Zhang, L. P., Blot, W., Yin, S. N., \& Hayes, R. B. (1996). Hematotoxicity among Chinese workers heavily exposed to benzene. American Journal of Industrial Medicine, 29(3), 236-46.PMCID: PMC1469765. http://dx.doi.org/10.1002/(SICI)1097-0274(199603)29:3<236::AID-AJIM3>3.0.CO;2-O

Schettler, G., \& Nossel, E. (1975). Arb, Med, Soz, Med, Prav, Med, 10, 25.

Sembulingam, K., \& Sembulingam, P. (2006). Essential of Medical physiology Chapter 7, Edi $4^{\text {th }}$, Jaypee Brothers, Medical Publishers, (p) Ltd., New Delhi $4^{\text {th }}$ Edition, India. 53. 
Soyinka, O. O., Adeniyi, F. A., \& Ajose, O. A. (2007) Biochemical parameters of liver function in artisans occupationally exposed to "vat dyes" Indian Journal of Occupational and $\begin{array}{llll}\text { Environmental } \quad \text { Medicine, } & 11(2), & \text { 76-79. } & \text { PMID: }\end{array}$ http://dx.doi.org/10.4103/0019-5278.34533

Stengel, B., Cenee, S., Limasset, J. C., Diebold, F., Michard, D., Druet, P., \& Hemon, D. (1998). Immunologic and renal markers among photogravure printers exposed to toluene. Scandinavian Journal of Work and Environmental Health, 24, 276-284. http://dx.doi.org/10.5271/sjweh.321

Stumph, M. J., Weir, F. W., \& Noall, M. W. (1985). Comparison of blood and brain toluene concentrations and circulating triglyceride levels resulting from acute and repeated exposures in rats. American Industrial Hygiene Association Journal, 46(5), 244-50. PMID: 4003275. http://dx.doi.org/10.1080/15298668591394752

Sukhodub, A. L. (1997). Activity of microsomal liver enzymes and blood glucose level in normal and benzene-treated rats of various ages. Ukrainskii Biokhimicheskii Zhurnal, 69(3), 119-21. PMID: 9505373

Swaen, G. M., van Amelsvoort, L., Twisk, J. J., Verstraeten, E., Slootweg, R., Collins, J. J., \& Burns, C. J. (2010). Low level occupational benzene exposure and hematological parameters. Chemico- Biological Interaction, 184(1, 2), 94-100. PMID: 20074561. http://dx.doi.org/10.1016/j.cbi.2010.01.007

Szadkowska-Stańczyk, I., Woźniak, H., \& Stroszejn-Mrowca, G. (2003). Health effects of occupational exposure among shoe workers, A review. Medycyna Pracy, 54(1), 67-71.PMID: 12731407.

Takahashi, S., Tanabe, K., Maseda, C., Shiono, H., \& Fukui, Y.(1988). Increased plasma free fatty acid and triglyceride levels after single administration of toluene in rabbits. Journal of Toxicology and Environmental Health, 25(1), 87-95. http://dx.doi.org/10.1080/15287398809531190

Tas, U., Ogeturk, M., Meydan, S., Kus, I., Kuloglu, T., Ilhan, N., Kose, E., \& Sarsilmaz, M. (2011). Hepatotoxic activity of toluene inhalation and protective role of melatonin. Toxicological and Industrial Health, 27(5), 465-73.doi: 10.1177/0748233710389853.PMID: 21343225

Teuscher, A. \& Richterich, P. (1971) Enzymatic method of glucose, Schweizerische Medizinische Wochenschrift, 101, 345-390.

Todd, L., Puangthongthub, S. T., Mottus, K., Mihlan, G., \& Wing, S. (2008). Health survey of workers exposed to mixed solvent and ergonomic hazards in footwear and equipment factory workers in Thailand. The Annals of Occupational Hygiene, 52(3), 195-205. http://dx.doi.org/10.1093/annhyg/men003

Trinder, P. (1969). Determination of Glucose in Blood Using Glucose Oxidase with an Alternative Oxygen Acceptor. Annual Clinical Biochemistry, 6, 24-25. 


\section{Macrothink}

Tsai, S. P., Wen, C. P., Weiss, N. S., Wong, O., Mcclellan, W. A., \& Gibson, R. L. (1983). Retrospective mortality and medical surveillance studies of workers in benzene areas of refineries. Journal of Occupational Medicine, 25(9), 685-692. PMID: 6631569. http://dx.doi.org/10.1097/00043764-198309000-00018

Ukai, H., Takada, S., Inui, S., Imai, Y., Kawai, T., Shimbo, S., \& Ikeda, M. (1994). Occupational exposure to solvent mixtures: effects on health and metabolism. Occupational Environmental Medicine, 51, 523-529. PMCID: PMC1128031. http://dx.doi.org/10.1136/oem.51.8.523

Ukai, H., Watanabe, T., Nakatsuka, H., Satoh, T., Liu, S. J., Qiao, X., Yin, H., Jin, C., Li, G. L., \& Ikeda, M. (1993). Dose-dependent increase in subjective symptoms among toluene-exposed workers. Environmental Research, 60(2), 274-89. ISSN: 0013-9351. http://dx.doi.org/10.1006/enrs.1993.1037

Uuksulainen, S. O., Heikkila, P. R., Olkinuora, P. S., \& Kiilunen, M. (2002). Self-reported occupational health hazards and measured exposures to airborne impurities and noise in shoe repair work. International Journal of Occupational and Environmental Health, 8(4), 320-327. 10773525

Uzma, N., Salar, B. M. K. M., Kumar, B. S., Aziz, N., David, M. A., \& Reddy, V. D. (2008). Impact of organicsolvents and environmental pollutants on the physiological function in petrol filling workers. International Journal of Environmental Research and Public Health, 5(3), 139-46. http://dx.doi.org/10.3390/ijerph5030139

Voss, J. U., Roller, M., \& Mangelsdorf, I. (2003). Nephrotoxicity of organic solvents, Federal Institute for Occupational Safety and Health, Dortmund, Berlin, Dresden.

Warnes, T., Jain, S., \& Smith, A. (2000). Hepatotoxic effects of workplace exposures. In: Baxter P, Adams P, Tar-Ching A (eds) Hunter diseases of occupations, 3rd edn. Arnold, London, p 501.

White, R. F., \& Proctor, S. P. (1997). Solvents and neurotoxicity. Lancet, 349, 9060, 1239-43.PMID: 9130958. http://dx.doi.org/10.1016/S0140-6736(96)07218-2

Wichmann, G., Mühlenberg, J., Fischäder, G., Kulla, C., Rehwagen, M., Herbarth, O., \& Lehmann, I. (2005). An experimental model for the determination of immunomodulating effects by volatile compounds. Toxicology In Vitro, 19(5), 685-93. PMID: 15885978. http://dx.doi.org/10.1016/j.tiv.2005.03.012

Wiwanikit, V. (2001). High serum alkaline phosphatase levels, a study in 81 Thai adult hospitalized patients. Bio Medical Center Family Practice, 2, 2. PMID: 11545676. http://dx.doi.org/10.1186/1471-2296-2-2

Xiao, J. Q., \& Levin, S. M. (2000). The diagnosis and management of solvent-related disorders. American Journal of Industrial Medicine, 37(1), 44-61. http://dx.doi.org/10.1002/(SICI)1097-0274(200001)37:1<44::AID-AJIM5>3.0.CO;2-K 


\section{Copyright Disclaimer}

Copyright reserved by the author(s).

This article is an open-access article distributed under the terms and conditions of the Creative Commons Attribution license (http://creativecommons.org/licenses/by/3.0/). 